
ISSN : 2615-1995, E-ISSN : 2615-0654

J. Madani., Vol. 2, No. 2, September 2019 (232 - 247)

(C)2018 Lembaga Kajian Demokrasi

dan Pemberdayaan Masyarakat (LKD-PM)

\title{
Analisis Faktor Kendala dan Non-Kendala Ketahanan Pangan, Pertanian, dan Perikanan Dalam Struktur Perekonomian Kota Tangerang Selatan
}

\author{
Iman Lubis \\ Fakultas Ekonomi, Universitas Pamulang \\ dosen01479@unpam.ac.id \\ Kholidah Tamami \\ Fakultas Ekonomi, Universitas Pamulang \\ kholidahtamami@gmail.com \\ Dien Mardiana Yulianti \\ Fakultas Ekonomi, Universitas Pamulang \\ diendiana1107@gmail.com
}

\begin{abstract}
Abstrak
Tujuan penelitian ini adalah untuk mengetahui peranan, program sekaligus kendala ketahanan pangan, pertanian, dan perikanan Kota Tangerang Selatan. Metode yang dilakukan adalah penelitian kualitatif yaitu dengan metode interview dan menggunakan dokumentasi dari Dinas Ketahanan Pangan, Pertanian, dan Perikanan Kota Tangerang Selatan dan metode interview pertanyaan tidak terstruktur kepada empat ketua kelompok tani. Hasil penelitian dari non-kendala pertanian Kota Tangerang Selatan adalah adanya peran dari Dinas Ketahanan Pangan, Pertanian dan Perikanan Kota Tangerang Selatan dalam membuat program di bidang pangan, pertanian, peternakan dan perikanan dalam meningkatkan produktivitas Kota Tangerang Selatan. Kendala pertanian Kota Tangerang Selatan adalah lahan pertanian sementara, tidak ada irigasi yang memadai, menurunnya generasi muda dalam berpartisipasi dalam kelompok tani, jauhnya membeli pupuk dan bibit, kurangnya pertemuan antara kelompok tani dan pemerintah, regulasi yang tidak dipahami oleh ketua kelompok tani, permodalan yang dilakukan secara pribadi disebabkan kelompok tani yang belum berbadan hukum, dan belum terintegrasinya pemasaran hasil panen ke petani melalui tekonologi terbaru karena sistem pembeliannya masih datang ke tempat panen dan memborong
\end{abstract}

Kata Kunci : Ketahanan Pangan, Konversi Lahan, Saluran Irigasi, Hasil Ternak, Perikanan, dan Partisipasi Kelompok Tani

\begin{abstract}
The purpose of this study was to determine the role, program as well as the constraints of food security, agriculture and fisheries in the City of South Tangerang. The method used is qualitative research, namely the interview method and using documentation from the South Tangerang City Food, Agriculture and Fisheries Service Office and the interview method for unstructured questions to four farmer group leaders. The research results from the non-constraints of agriculture in the city of South Tangerang are the role of the South Tangerang City Food, Agriculture and Fisheries Service in making programs in the fields of food, agriculture, livestock and fisheries in increasing the productivity of the city of South Tangerang. The agricultural constraints of the city of South Tangerang are temporary agricultural land, there is no adequate irrigation, the decline in the
\end{abstract}


younger generation in participating in farmer groups, far buying fertilizers and seeds, lack of meetings between farmer groups and the government, regulations not understood by the head of farmer groups, capital carried out privately due to farmer groups that have not been incorporated, and the integration of marketing of crops to farmers through the latest technology because the purchasing system still comes to the harvest place and buys.

Keywords : Food Security, Land conversion, Irrigation, Livestock Production, Fisheries, Participating Farmer Groups

\section{PENDAHULUAN}

Di Indonesia, menurut (Pratama Y. C., 2014) kemiskinan dapat dijelaskan oleh inflasi, pendapatan per kapita variabel dan Indeks pembangunan manusia sebanyak 56\%. Jika inflasi meningkat maka akan menurunkan daya beli masyarakat atau pendapatan riil menurun yang mengakibatkan turunnya tingkat konsumsi maka kemiskinan pun bertambah. Tingkat pendapatan yang rendah juga membuat masyarakat sulit untuk melanjutkan ke jenjang pendidikan yang lebih baik sehingga skill dan kompetensi masyarakat tidak dapat bersaing untuk mendapatkan penghasilan yang lebih baik.

Didit Herdiawan (2018) dalam buku yang berjudul Industri Pangan Maritim menegaskan bahwa pemenuhan pangan adalah sesuatu yang krusial bagi setiap bangsa dan negara. Sebagai salah satu kebutuhan dasar, pemenuhan pangan memiliki peran penting dalam pembangunan dan mestilah menjadi perhatian utama pemerintah. Ketercukupan pangan, bagaimanapun, adalah salah satu faktor penting dari tercipta dan terjaganya stabilitas suatu negara.

Sedikitnya produksi pangan dalam Kota Tangerang Selatan membuat kota tersebut bergan- tung kepada wilayah lain untuk pemenuhan kebutuhan pangan. Bahkan kecenderungan tersebut membuat harga pangan di pasar biasa tidak kalah mahal dibandingkan harga di mal. Hal ini sangat rentan dikarenakan tingkat inflasi pada daerah tersebut tidak bisa dikontrol.

Permasalahan Kota Tangerang Selatan adalah menurunnya tenaga kerja/rumah tangga yang berprofesi sebagai petani yang dimulai sejak kota Tangerang Selatan berdiri. Dari tabel di bawah ini dapat disimpulkan semakin sedikitnya rumah tangga yang berkontribusi pada sektor pertanian atau rumah tangga yang langsung berhubungan dengan hasil pertanian sehingga ketergantungan dengan wilayah lain semakin dalam. Tabel 1 merupakan perbandingan rumah tangga usaha tani dan perusahaan berusaha tani berbadan hukum pada tahun 2003 dan 2013.

Terlihat pada tabel 1 bahwa kelompok tani mengalami penurunan drastis misalnya di Setu rumah tangga usaha tani dari 2.983 turun ke 926; Serpong turun dari 3.793 turun ke 621; Pamulang dari 6.352 turun ke 798; Ciputat 357 turun ke 484; Ciputat Timur dari 714 turun ke 484; Pondok Aren dari 5.290 turun ke 887; Serpong Utara dari 1.968 turun ke 761; keseluruhan kota Tangerang

\begin{tabular}{|c|c|c|c|c|c|c|}
\hline \multirow[b]{2}{*}{ No } & \multirow[b]{2}{*}{ Kecamatan } & \multicolumn{2}{|c|}{2003} & \multicolumn{3}{|c|}{2013} \\
\hline & & $\begin{array}{l}\text { Rumah Tangga } \\
\text { Usaha Pertanian }\end{array}$ & $\begin{array}{l}\text { Perusahaan Pertanian } \\
\text { Berbadan Hukum }\end{array}$ & $\begin{array}{l}\text { Rumah Tangga } \\
\text { Usaha Pertanian }\end{array}$ & $\begin{array}{l}\text { Perusahaan Pertanian } \\
\text { Berbadan hukum }\end{array}$ & $\begin{array}{l}\text { Non-rumah Tangga } \\
\text { Usaha Pertanian }\end{array}$ \\
\hline (1) & (2) & (3) & (4) & (5) & (6) & (7) \\
\hline 1 & Setu & 2.983 & - & 926 & - & 3 \\
\hline 2 & Serpong & 3.793 & 1 & 621 & - & - \\
\hline 3 & Pamulang & 6.352 & - & 798 & - & - \\
\hline 4 & Ciputat & 357 & - & 484 & 1 & - \\
\hline 5 & Ciputat Timur & 714 & - & 484 & - & 1 \\
\hline 6 & Pondok Aren & 5.290 & - & 887 & - & 1 \\
\hline 7 & Serpong Utara & 1.968 & - & 761 & - & 1 \\
\hline \multicolumn{2}{|c|}{ Tangerang Selatan } & 21.457 & 1 & 4.961 & 1 & 6 \\
\hline \multicolumn{7}{|c|}{ Sumber: Angka Sementara Hasil Sensus Pertanian 2013} \\
\hline
\end{tabular}


Selatan dari 21.457 rumah tangga pertanian menjadi 4.961 rumah tangga pertanian.

Dari permasalahan di atas sudah jelas bahwa keterpenuhan dari produktivitas Kota Tangerang Selatan dalam memenuhiketersediaan pangan dari dalam kota sangat rendah sehingga bergantung dengan daerah lain. Kontribusi ekonomi dari pertanian dan perikanan Kota Tangerang Selatan juga sangat rendah dalam struktur perekonomian sehingga terlihat secara jelas adanya kendalakendala yang menyebabkan output dari pertanian tidak bisa memenuhi kecukupan kebutuhan warga Kota Tangerang Selatan. Beberapa permasalahan yang paling penting pertanian adalah kurangnya lahan, kurangnya infrastruktur, kurangnya sarana produksi, regulasi yang belum dijalankan, kurangnya dukungan kelembagaan dan sumber daya manusia, dan permodalan.

Walaupun terdapat kendala tentu saja dari pemerintahan Kota Tangerang Selatan tidak akan membiarkan kendala itu berlarut-larut. Pasti ada program-program untuk peningkatan defisit ketersediaan pangan dari dalam kota, ketidaktahuan tentang seberapa kuat peran Dinas Ketahanan Pangan, Pertanian, dan Perikanan tentang pemberian dukungan ke masyarakat menjadi semacam motivasi bagi peneliti untuk memulai penelitian ini selain kendala yang sudah dikembangkan di atas.

Tujuan dari penelitian ini adalah mendeskripsikan peranan Dinas Ketahanan Pangan, Pertanian, dan Perikanan, rencana program-program peningkatan ketahanan pangan, pertanian dan perikanan Kota Tangerang Selatan, dan kendala dan non-kendala dari peningkatan produksi pangan, pertanian dan perikanan. Sedangkan harapan dari penelitian ini adalah menambah literature dalam mencapai target pangan Kota Tangerang Selatan, menambahkan sumber daftar pustaka dan bertambahnya wawasan dalam kendala-kendala dan non-kendala ketahanan pangan, pertanian, dan perikanan Kota Tangerang Selatan.

Tangerang Selatan disarankan untuk meneruskan perbaikan dalam program peningkatan ketersediaan pangan, pertanian dan perikanan. Evaluasi faktor eksternal adalah peluang akses pasar di Tangerang Selatan sangat besar dan pe- luang paling kecil adalah adanya kovergensi antar sektor, sedangkan ancaman terbesar adalah di keterbatasan lahan dan ancaman terkecil adalah daya tarik sektor pertanian sangat rendah (Karini, 2013). Kekuatan Kota Tangerang Selatan terbesar adalah komitmen dari kepala daerah dan kekuatan dan kekuatan terkecil ada di pembangunan pertanian melalui RPJMD, sedangkan kelemahan terbesar adalah belum adanya perwal dan Kelemahan terkecil adalah ketersediaan sarana yang belum tercukupi.

Dari penjelasan di atas maka kami sangat tertarik dengan permasalahan pangan sehingga judul yang akan kami ambil adalah "Analisis Faktor Kendala Dan Non Kendala Ketahanan Pangan Pertanian Dan Perikanan Dalam Struktur Perekonomian Kota Tangerang Selatan".

\section{METODE}

\section{Pendekatan Penelitian}

Penelitian ini menggunakan analisis kualitatif. Analisis data kualitatif berbeda dengan analisis kuantitatif yang metode dan prosedurnya sudah pasti dan jelas. Walaupun analisis kualitatif ini tidak menggunakan teori secara pasti seperti halnya kuantitatif, tetapi keabsahan dan kevalidan temuannya juga diakui sejauh peneliti masih menggunakan kaidah-kaidah penelitian. Menurut Patton dalam Kristi Poerwandari (2011), peneliti wajib memonitor dan melaporkan proses dan prosedur-prosedur analisisnya sejujur dan selengkap mungkin. Analisis data kualitatif juga berbeda dengan kuantitatif yang cara analisisnya dilakukan setelah data terkumpul, tetapi analisis kualitatif dilakukan sepanjang penelitian dari awal hingga akhir. Hal ini dilakukan karena peneliti kualitatif mendapat data yang membutuhkan analisis sejak awal penelitian. Bahkan hasil analisis awal akan menentukan proses penelitian selanjutnya.

Menurut Lexy J. Moleong (2011), proses analisis data kualitatif dimulai dengan menelaah seluruh data yang tersedia dari berbagai sumber, yaitu wawancara, pengamatan yang sudah dituliskan dalam catatan lapangan, dokumen pribadi, dokumen resmi, gambar foto, dan sebagainya. 
Setelah ditelaah maka mereduksi data, penyusunan satuan dan terakhir penafsiran data.

Mereduksi data berarti merangkum, memilih hal-hal yang pokok, memfokuskan pada halhal yang penting, dicari tema dan polanya dan membuang yang tidak perlu. Reduksi data dapat dilakukan dengan jalan abstraksi yang merupakan usaha membuat rangkuman yang inti, proses dan pernyataan-pernyataan yang perlu dijaga sehingga tetap berada dalam penelitian. Dapat disebutkan bahwa proses reduksi data ini dilakukan secara terus menerus saat melakukan penelitian untuk menghasilkan catatan inti dari data yang diperoleh dari hasil penggalian data. Oleh sebab itu, tujuan mereduksi data adalah menyederhanakan data yang diperoleh selama penggalian data di lapangan karena data yang didapat di lapangan sangat rumit dan tidak semuanya sesuai tema.

Penyajian data menurut Miles, Hubermen dan Saldana (2014) bahwa penyajian data ini ialah sekumpulan informasi tersusun yang memberi kemungkinan adanya penarikan kesimpulan. Langkah ini dilakukan dengan menyajikan sekumpulan informasi yang tersusun yang memberi kemungkinan adanya penarikan kesimpulan disebabkan data-data yang diperoleh selama proses penelitian kualitatif adalah bersifat naratif sehingga memerlukan penyederhanaan tanpa mengurangi isinya. Pada tahap penelitian ini kami berupaya mengklasifikasikan dan menyajikan data sesuai dengan pokok permasalahan yang diawali dengan pengkodean pada setiap subpokok permasalahan.

Kesimpulan atau verifikasi adalah tahap akhir dalam proses analisa data. Pada bagian ini merupakan tahap pengambilan kesimpulan dari data yang diperoleh. Kegiatan ini dimaksudkan untuk mencari makna data yang dikumpulkan dengan mencari hubungan, persamaan atau perbedaan. Penarikan kesimpulan bisa dilakukan dengan jalan membandingkan kesesuaian pernyataan dari subyek penelitian dengan makna yang terkandung dengan konsep-konsep dasar dalam penelitian ini.

\section{Jenis Penelitian}

Jenis penelitian ini adalah penelitian kualitatif.
Penelitian yang bertujuan untuk menggambarkan dan menganalisis fenomena, aktivitas sosial, sikap, kepercayaan, persepsi, pemikiran orang secara individual dan kelompok. Penelitian kualitatif memiliki dua tujuan yaitu pertama, untuk menggambarkan dan mengungkap, kedua, untuk menggambarkan dan menjelaskan.

\section{Lokasi Penelitian}

Lokasi penelitian adalah Kota Tangerang Selatan. Dinas yang dituju adalah dinas ketahanan pangan pertanian dan perikanan masuk ke dalam penyuluh pertanian, kelompok tani Tangerang Selatan dan perkembangan pihak-pihak yang terkait sesuai dengan permasalahan yang berkembang di Kota Tangerang Selatan.

\section{Subjek dan Objek Penelitian}

1. Subjek Penelitian

Subjek penelitian ini adalah kami sendiri yang dalam hal ini memperoleh informasi secara langsung dari Dinas Ketahanan Pangan Penelitian dan pengurus-pengurus luaran dari Dinas Ketahanan Pangan seperti penyuluh pertanian dan kelompok tani.

2. Objek Penelitian

Objek penelitian adalah analisa kendala dan non kendala dari ketahanan pangan serta program-program apa yang dijalankan untuk kenaikan ketahanan pangan di Kota Tangerang Selatan

\section{Teknik Pengumpulan Data}

Untuk mendapatkan data yang objektif maka dalam pendekatan ini, peneliti menggunakan metode pengumpulan data yang bersifat kualitatif dengan langkah-langkah sebagai berikut:

1. Observasi

Observasi adalah usaha untuk memperoleh dan mengumpulkan data dengan melakukan pengamatan langsung di lapangan terhadap suatu kegiatan secara akurat serta mencatat fenomena yang muncul dan mempertimbangkan hubungan antara aspek dalam fenomena tersebut.

2. Studi Dokumentasi

Studi dokumentasi, yaitu peneliti mengum- 
pulkan, membaca dan mempelajari berbagai macam bentuk data yang diambil dari BPS dan Dinas Ketahanan Pangan Pertanian dan Perikanan Kota Tangerang Selatan.

\section{Sumber Data}

Sumber data yang digunakan dalam penelitian ada dua macam yaitu data primer dan data sekunder.

1. Data Primer terbagi menjadi dua sumber data, yaitu:

a. Utama, yaitu data yang diperoleh secara langsung dari objek penelitian yaitu penyuluh pertanian.

b. Pendukung, yaitu data yang diperoleh dari kelompok tani di Kota Tangerang Selatan.

2. Data Sekunder, yaitu data yang diperoleh dari catatan-catatan, dokumen, foto, maupun materi tertulis lainnya dari BPS dan Dinas Ketahanan Pangan dan Perikanan.

\section{Langkah-langkah Penelitian}

Penelitian ini dilakukan dengan langkahlangkah sebagai berikut:

1. Melakukan observasiawaldiDinas Ketahanan Pangan dan Perikanan Kota Tangerang Selatan untuk mengetahui pengembangan program untuk meningkatkan ketahanan Pangan kota Tangerang Selatan dan menentukan subyek penelitian

2. Melakukan observasi awal di tempat luaran yang membantu program ketahanan pangan di Kota Tangerang Selatan

3. Melakukan interview ke penyuluh pertanian dan kelompok tani

4. Melakukan kegiatan Dokumentasi

5. Menganalisis Data

6. Membuat simpulan

\section{Keabsahan dan Keajegan Penelitian}

Kriteria keabsahan dan keajegan yang diperlukan dalam penelitian ini adalah sebagai berikut:

1. Keabsahan Konstruk

a. Triangulasi Data

Menggunakan berbagai sumber data seperti dokumen, arsip, hasil wawancara, hasil observasi atau juga dengan mewawancarai lebih dari satu subjek yang dianggap memiliki sudut pandang yang berbeda-beda.

b. Triangulasi Pengamat

Adanya pengamat di luar peneliti yang turut memeriksa hasil pengumpulan data. Pada penelitian ini, rekan sesama dosen yang bertindak sebagai pengamat (expert judgement) yang memberikan masukan terhadap pengumpulan data

c. Triangulasi Teori

Penggunaan berbagai teori yang berlainan untuk memastikan bahwa data yang dikumpulkan sudah memenuhi syarat. Pada penelitian ini menggunakan Bab II sebagai pembanding hasil penelitian.

d. Triangulasi Metode

Penggunaan berbagai metode untuk meneliti suatu hal, seperti metode wawancara, metode observasi dan dokumentasi. Pada penelitian ini peneliti melakukan metode wawancara, observasi, dan dokumentasi saat FGD dilakukan.

2. Keajegan (Reliabilitas)

Keajegan mengacu pada kemungkinan peneliti selanjutnya memperoleh hasil yang sama apabila penelitian dilakukan sekali lagi dengan subjek yang sama. Hal ini menunjukkan bahwa konsep keajegan penelitian kualitatif selain menekankan pada selain penelitian juga pada pengolahan dan pengmpulan data.

\section{Teknik Analisis Data}

1. Reduksi Data meliputi penyeleksian data melalui deskripsi atau gambaran singkat dan pengelompokan data yang dilakukan ke dalam kualifikasi yang telah ditentukan. Data dianalisis dengan pertanyaan penelitian yang relevan dengan ketahanan pangan pertanian di Kota Tangerang Selatan.

2. Penyajian Data dilakukan dalam rangka mengorganisasikan data yang merupakan kegiatan penyusunan informasi secara sistematik dari reduksi data sehingga memudahkan 
membaca data.

3. Triangulasi Data dilakukan untuk mengecek keabsahan data. Triangulasi data dilakukan dengan cara mencocokkan semua data yang diperoleh dari semua sumber yang telah diperoleh asa.

4. Penarikan Kesimpulan dalah pemberian makna pada data yang diperoleh dari penyajian data. Penarikan simpulan berdasarkan hasil dari semua data yang diperoleh.

\section{Jadwal Penelitian}

Waktu penelitian mulai Oktober 2018-Agustus 2019. Tahapan pelaksanaan penelitian meliputi:

a. pelaksanaan persiapan penelitian;

b. pelaksanaan pra penelitian;

c. sosialisasi dan penetapan lokasi penelitian;

d. pengadaan alat dan bahan penelitian;

e. pelaksanaan studi kepustakaan;

f. pengambilan data di lapangan;

g. analisis data;

h. penyusunan laporan penelitian;

i. pengiriman laporan penelitian;

j. publikasi hasil penelitian.

\section{HASIL dan PEMBAHASAN}

Hasil

Peranan Dinas Ketahanan Pangan, Pertanian dan Perikanan

Dinas Ketahanan Pangan, Pertanian dan Perikanan merupakan perangkat daerah yang melaksanakan urusan pangan, pertanian dan kelautan dan perikanan sesuai dengan Peraturan Daerah Kota Tangerang Selatan Nomor 8 tahun 2016 tentang Organisasi Perangkat Daerah.

Tugas Dinas Ketahanan Pangan, Pertanian dan Perikanan adalah merencanakan, melaksanakan, mengarahkan, mengawasi dan mengendalikan kegiatan di bidang pertanian, peternakan, dan perikanan dan ketahanan pangan sesuai kebijakan Pemerintah Daerah.

Fungsi Dinas Ketahanan Pangan, Pertanian dan Perikanan adalah:

1. Perumusan, penetapan, pelaksanaan kebijakan strategis dan teknis di bidang keterse- diaan dan distribusi pangan, konsumsi dan keamanan pangan, pertanian dan peternakan serta perikanan;

2. Perumusan, penetapan, pelaksanaan program dan anggaran bidang ketersediaan dan distribusi pangan, konsumsi dan keamanan pangan, pertaniandan peternakan serta perikanan;

3. Pembinaan, pengawasan, pengendalian, pemantauan pelakanaan tugas bidang ketersediaan dan distribusi pangan, konsumsi dan keamanan panagan, pertanian dan peternakan serta perikanan;

4. Pembinaan, pengawasan, pengendalian, pemantauan pelaksanaan tugas bidang perencanaan, keuangan serta umum dan kepegawaian;

5. Pengkoordinasian pelaksanaan bidang ketersediaan dan distribusi pangan, konsumsi dan keamanan pangan, pertanian dan peternakan serta perikanan dengan lembaga-lembaga terkait;

6. Pelaksanaan evaluasi dan pelaporan tugas dan fungsi dan fungsi lingkup dinas;

7. Pelaksanaan penanganan kerawanan pangan kota;

8. Pelaksanaan pencapaian target konsumsi pangan perkapita/tahun sesuai dengan angka kecukupan gizi;

9. Pelaksanaan pengelolaan cadangan kota;

10. Penetapan tidak lanjut hasil pengawasan keamanan pangan segar;

11. Penetapan hasil perhitungan pola pangan harapan $(\mathrm{PPH})$ tingkat konsumsi;

12. Pelaksanaan promosi konsumsi pangan yang beragam, bergizi seimbang dan aman (B2SA) berbasis sumber daya lokal, produk pertanian, peternakan dan perikanan;

13. Pelaksanaan pengawasan dan pengembangan penggunaan sarana/prasarana/sumber daya pertanian;

14. Pelaksanaan penerbitan rekomendasi Izin Usaha Pertanian (IUP);

15. Pelaksanaan pengawasan dan perkembangan sarana dan prasarana peternakan;

16. Pelaksanaan penetapan Surat Izin Praktek (SIP) dokter hewan; 
17. Pelaksanaan penjaminan kesehatan hewan, penutupan dan pembukaan daerah wabah penyakit hewan menular;

18. Pelaksanaan penerbitan rekomendas izin usaha produksi benih/bibit ternak dan pakan, fasilitas pemeliharaan hewan, klinik hewan, pasar hewan, rumah potong hewan ( $\mathrm{RPH})$ serta produk hewan $(\mathrm{PH})$;

19. Pelaksanaan penerbitan rekomendasi izin usaha pengecer (toko, retail, sub-distributor) obat hewan;

20. Pelaksanaan penerbitan rekomendasi Izin Usaha Perikanan (IUP) di bidang pembudidayaan ikan;

21. Pelaksanaan penerbitan rekomendasi Izin Usaha Perikanan (IUP) di bidang pengolahan dan pemasaran produk hasil perikanan;

22. Pelaksanaan penerbitan tanda pencatatan usaha pembudidayaan ikan (TPUPI);

23. Pelaksanaan pemberdayaan usaha kecil pembudidayaan ikan serta pengolahan dan pemasaran produk hasil perikanan;

\section{Program Dinas Ketahanan Pangan, Pertanian, dan Perikanan}

Dalam rangka mendukung misi ke-5 kota Tangerang Selatan yang tertuang dalam RJMPD "meningkatkan fungsi dan peran kota sebagai sentra perdagangan jasa" maka Dinas Ketahanan Pangan, Pertanian dan Perikanan Kota Tangerang Selatan mengembangkan sektor pertanian perkotaan, ketersediaan pangan dengan cara meningkatkan jumlah wirausaha agrobisnis, meningkatnya potensi produksi perikanan, dan terjaminnya ketersediaan pangan. Program Ketahanan Pangan adalah sebagai berikut:

1. Kegiatan Pengembangan Kawasan Mandiri Pangan
a. Peningkatan Kapasitas SDM Kelompok Wanita Tani
b. Pelatihan dan Pembuatan Demplot Kawasan Rumah Pangan Lestari

2. Kegiatan Pengembangan Pangan

3. Kegiatan sosialisasi pertanian perkotaan

4. Kegiatan Pemanfaatan Pekarangan Untuk Kegiatan Gebyar pertanian perkotaan

a. Workshop pertanian perkotaan
b. Pameran Pertanian perkotaan
c. Gemar bertani bagi anak-anak sekolah

5. Kegiatan pengembangan pertanian lahan sempit
a. Pengembangan vertical gardening
b. Pengembangan hydrophonic

6. Penguatan cadangan pangan

7. Ketersediaan informasi pasokan, harga dan akses pangan
a. Laporan Berkala Sistem Kewaspadaan Pangan Daerah (SKPD)
b. Penyusunan Neraca Bahan Makanan (NBM)
c. Penyusunan Analisis Sistem Kewaspa- daan Pangan dan Gizi (SKPG)
d. Penyusunan Peta Ketahanan dan Keren- tanan Pangan (FVSA)
e. Pengembangan Sistem Jaringan Infor- masi Ketersediaan Pangan

8. Manajemen Logistik
a. Kajian Pemetaan Rantai Pasok dan Ja- ringan Distribusi Bahan Pangan

9. Keamanan Pangan

Kegiatan Analisis dan Penyusunan Pola Konsumsi dan Suplai Pangan
a. Pelatihan Penyusunan Pola Konsumsi dan Suplai Pangan
b. Pengumpulan dan Pengolahan Data Survei Pola Konsumsi Pangan
c. Analisis Data dan Pelaporan Survei Pola Konsumsi dan Suplai Pangan

10. Kegiatan Peningkatan Mutu Pangan
a. Lomba Cipta Menu
b. Kajian Identifikasi Pangan Lokal
c. Pameran Pangan Nusantara

11. Kegiatan Peningkatan Keamanan Pangan

a. Pengawasan Keamanan Pangan Triwulan

b. Pelatihan Pengolahan Pangan Lokal

c. Sosialisasi Peningkatan Mutu dan Keamanan Pangan

Konsumsi daging pemerintah Kota Tangerang Selatan sebesar 2.960,78 ton/tahun.Konsumsi tersebut dipenuhi dengan 90 persen sapi potong impor dan 10 persen didatangkan dari Bali dan NTT. Di kota Tangerang Selatan terdapat 12 rumah potong hewan dengan kapasitas potong 36 ekor/hari atau 1.080 ekor/bulan. Jumlah ini setara 
dengan 1.998,47 ton/ tahun daging sapi impor dan 294,81 ton/tahun daging sapi lokal. Kekurangan konsumsi daging tersebut pemerintah Kota Tangerang Selatan berencana untuk mengadakan kerjasama dengan Jawa Timur. Alasan pertama adalah populasi ternak Jawa Timur sebesar 4.692.455 ekor, produksi daging sapi sebesar $100.172 .000 \mathrm{~kg}$ sedangkan konsumsi daging sapi mencapai $93.785 .226 \mathrm{~kg}$, rumah potong hewan memotong sapi 300 potong/hari. Biaya retribusi hanya 50 ribu/ekor. Alasan kedua harga di Jawa Timur relatif stabil karena Jawa Timur sudah memiliki pusat informasi pasar di setiap pasar hewan. Program Pengembangan Peternakan adalah sebagai berikut:

1. Pembangunan puskewan dan unit desa mandiri benih (DAK)
a. Pembangunan PUSKEWAN
b. Pembangunan Unit Desa Mandiri Benih

2. Pelatihan Pengembangan Peternakan

a. Temu teknis budidaya Jangkrik, Kroto, dan Ulat Jerman

b. Sosialisasi gemar beternak hewan kesayangan di usia muda

c. Temu teknis peternakan perkotaan

3. Kegiatan Pengadaan Fasilitasi Kesehatan Hewan dan Ternak

a. Perumusan pelayanan kesehatan hewan di Puskewan

b. Sosialisasi pelayanan PUSKEWAN

c. Pelayanan Kesehatan Hewan

d. Sosialisasi dan pelayanan Kesmavet

4. Kegiatan Fasilitasi Kesehatan Hewan

a. Pelayanan kesehatan hewan

b. Pendataan dan pemetaan penyakit hewan

c. Sosialisasi dan pencegahan penyakit zoonosis

d. Penyediaan obat dan sarana kesehatan hewan

5. Kegiatan Pengendalian dan Pencegahan Penyakit Hewan Qurban

a. Pendataan perdagangan dan pemotongan hewan kurban

b. Sosialisasi pemotongan hewan qurban kepada masyarakat

c. Pengawasan kesehatan dan kelayakan hewan qurban

6. Kegiatan Fasilitasi Kesehatan Masyarakat Veteriner

a. Sosialisasi peningkatan hygiene sanitasi

b. Sosialisasi dan pelayanan kesmavet

c. Pendataan perdagangan dan pemotongan hewan kurban

d. Sosialisasi pemotongan hewan qurban kepada masyarakat

e. Pengawasan kesehatan dan kelayakan hewan qurban

Program Pengembangan Perikanan adalah sebagai berikut:

1. Kegiatan Pembinaan dan Pengembangan Perikanan

a. Sosialisasi Sertifikasi Cara Budidaya/ Pembenihan Ikan yang Baik (CBIB/ CPIB)

b. Aplikasi Teknologi Budidaya Perikanan Darat

c. Pelatihan Pembuatan Pakan Ikan Alternatif

d. Pengembangan Kolam Pencontohan

e. Penyusunan Perwal Usaha Budidaya Perikanan

f. Kajian Zonasi Usaha Budidaya Perikanan

g. Validasi Data Usaha Budidaya Perikanan

h. Introduksi Usaha Budidaya Ikan Hias

i. Pengembangan Budidaya Ikan Hias

2. Kegiatan Pengembangan Sistem Kesehatan Ikan dan Lingkungan Pembudidayaan Ikan

a. Sosialisasi Kesehatan Ikan dan Lingkungan di Perairan Umum

b. Pembinaan dan Pengawasan Kesehatan Ikan dan Lingkungan di Tingkat Praktisi

c. Pelatihan dan Vaksinasi Ikan

d. Restocking Ikan di Perairan Umum

e. Pelatihan Kultur Cacing Rambut

f. Sosialisasi dan Pembentukan Kelompok Masyarakat Pengawas (POKMASWAS) pada lingkungan perairan umum

g. Pelatihan dinamika kelembagaan kelompok POKMASWAS

h. Pembinaan dan Pengawasan Kesehatan Ikan di Tingkat Praktisi Usaha Perikanan

i. Temu usaha pengusaha obat dan pakan ikan dengan para pelaku pembudidaya 
ikan

j. Pelatihan, pencegahan, pengawasan hama dan penyakit ikan

3. Kegiatan Pengembangan sarana dan prasarana kesehatan ikan dan lingkungan pembudidaya ikan
a. Sosialisasi Peraturan Daerah tentang usaha Perikanan
b. Pengadaan Sarana dan Prasarana Kese- hatan Ikan dan Lingkungan
c. Penyusunan Perwal Tentang Perikanan
d. Sosialisasi Perwal tentang pengawasan usaha perikanan
e. Pengadaan Obat Ikan

4. Pembangunan Balai Benih Ikan (BBI) Lokal Kota Tangerang Selatan Tahap I (DAK)

5. Kegiatan Pembibitan dan Perawatan Ternak

a. Inseminansi Buatan (IB) dan Perawatan Kesehatan Sapi Betina di Kota Tangerang Selatan

b. Monitoring dan evaluasi kapasitas reproduksi ternak pada sapi betina di Kota Tangerang Selatan

6. Kegiatan Pendistribusian Bibit Ternak kepada Masyarakat
a. Pengembangan Ternak Ruminansia Kecil
b. Pengembangan Budidaya Domba Bagi KWT

7. Kegiatan Pengembangan Produksi Peternakan
a. Pengadaan Sarana Prasarana Produksi Peternakan
b. Pendistribusian Ternak Kepada Masya- rakat
c. Pengawasan Mutu dan Peredaran Pakan Ternak
d. Temu Teknis Peternakan Perkotaan
e. Pelayanan Reproduksi Ternak

8. Kegiatan Pembangunan Demplot Pertanian

9. Kegiatan Magang Budidaya Perikanan

10. Kegiatan Pengembangan Penanganan Pasca Panen Bidang Peternakan
a. Pelatihan Manajemen Pemotongan dan Pengolahan Ternak Unggas
b. Pelatihan Pengolahan Produk Hewan untuk Kelompok Wanita Tani (KWT),

\section{PKK dan P2WKSS}

c. Pelatihan Pengolahan Susu Kambing untuk Kelompok Wanita Tani (KWT) Kelurahan Ciater

d. Fasilitasi Penjualan Produk Peternakan

e. Promosi Pameran Produk Peternakan

f. Pelatihan Pengolahan Hasil Produksi Peternakan

g. Pelatihan Pengemasan Hasil Produksi Peternakan

h. Pelatihan Pemasaran Hasil Produksi Peternakan

11. Kegiatan Sosialisasi Hasil Produksi dan Teknologi Peternakan
a. Sosialisasi informasi Undang-Undang Nomor 41 Tahun 2014 Tentang Peter- nakan
b. Monitoring Pengawasan ke Para Pelaku Usaha Bidang Peternakan

12. Kegiatan temu usaha perikanan
a. Temu usaha perikanan
b. Diseminasi hasil penelitian perikanan

13. Kegiatan Pengembangan Bibit Ikan Unggul
a. Identifikasi dan Verifikasi Kelompok
b. Pelatihan Budidaya Ikan Lele dan Patin
c. Pengembangan Budidaya Ikan Lele dan Patin
d. Pelatihan Budidaya Ikan Mas dan Nila
e. Pengembangan Budidaya Ikan Mas dan Nila
f. Pelatihan Budidaya Ikan Gurame dan Bawal
g. Pengembangan Budidaya Ikan Gurame dan Bawal
h. Pelatihan Budidaya Ikan Hias

\section{Kendala dan Non-kendala Kota Tangerang Selatan}

Pada penelitian ini peneliti melakukan interview ke beberapa pihak pertama ke pihak Dinas Ketahanan Pangan, Pertanian, dan Perikanan Kota Tangerang Selatan dan Kelompok Tani. 


\begin{tabular}{|c|c|c|}
\hline \multicolumn{3}{|c|}{ Tabel 2. Daftar Wawancara Penyuluh Pertanian } \\
\hline NO & PENYULUH PERTANIAN & KECAMATAN \\
\hline 1 & Pak Febry Putra & Serpong \\
\hline 2 & Pak Adiman & Pondok Aren \\
\hline 3 & Ibu Ida & Setu \\
\hline 4 & Pak Irwan & Seluruh kecamatan \\
\hline
\end{tabular}

Pada tanggal 12 Juni 2019 pukul 15.00 di kantor Dinas Ketahanan Pangan Kota Tangerang Selatan peneliti mengajukan beberapa pertanyaan mengenai kendala dan non-kendala pangan kota Tangerang Selatan. Menurut, Pak Febry bahwa Tangerang Selatan memiliki kendala pertama dengan lahan karena sebesar 70 persen tanah Kota Tangerang dimiliki oleh pihak developer rumah dan 30 persennya adalah sisanya. Apalagi di kecamatan Serpong, hampir semuanya dikuasai oleh developer. Walaupun dikuasai developer. Kecamatan yang memiliki tanah paling kosong dan paling luas adalah di daerah setu namun tanah itu bukan milik warga, tanah tersebut milik pengembang rumah yang belum terpakai. Tanah tersebut dapat digunakan untuk lahan pertanian tetapi tidak dapat dimiliki. Kendala kedua adalah kelembagaan kelompok tani masih banyak yang belum menjadi badan hukum sehingga bantuan yang berasal dari pemerintah menjadi lebih sulit karena hibah tidak bisa didistribusikan jika kelompok tani tidak memiliki badan hukum. Disebabkan sedikitnya badan hukum yang mengelola pertanian dan tidak adanya tanah yang secara kepemilikan diperuntukkan untuk pertanian maka bantuan dari pemerintah pusat sangat sedikit untuk pertanian Kota Tangerang Selatan. Kendala ketiga adalah budaya, menurut Pak Adiman masih ada beberapa kelompok tani yang menanam sesuatu bukan karena kebutuhan tetapi karena budaya turun temurun. Mereka tidak memikirkan untung atau rugi, yang mereka lakukan hanya melakukan sesuai dengan kebiasaan, misalnya di Kecamatan Pondok Aren, musim apapun, ada petani yang tetap menanam padi walaupun tanaman itu bukan sumber utama penghasilan petaninya.

Fokus yang lain, bantuan yang diberikan oleh Dinas adalah alat peraga, rumah bibit dan workshop pelatihan. Alat peraga produksi dipin- jamkan untuk petani menjalankan proses produksi. Rumah bibit baru saja diberikan untuk beberapa kelompok tani yang sudah mapan dan workshop pelatihan dilakukan untuk menopang keberlangsungan petani. Ditambah lagi 1000 tanam pot bawang untuk menanggulangi laju inflasi yang diberikan oleh corporate sosial responsibilities Bank Indonesia sebagai upaya penahan laju inflasi.

Kendala keempat adalah regulasi. Adanya otonomi daerah dan fungsi perkotaan membuat pertanian tidak menjadi perhatian pokok untuk Kota Tangerang Selatan dan menjadi tumpang tindih. Permodalan bagai masyarakat rata-rata merupakan modal pribadi dan unsur perbankan belum ada yang bekerja sama dengan dinas untuk melakukan stimulus permodalan.

Pada interview hari Senin, 17 Juni 2019 ke empat titik lokasi kelompok yang berbeda yaitu sebagai berikut:

\begin{tabular}{|c|l|c|c|}
\hline \multicolumn{4}{|c}{ Tabel 3. Daftar Wawancara Kelompok Tani } \\
\hline NO & \multicolumn{1}{|c|}{ NAMA } & $\begin{array}{c}\text { KELOMPOK TANI } \\
\text { KECAMATAN }\end{array}$ \\
\hline 1 & Bapak Zakaria & $\begin{array}{c}\text { Harapan Baru } \\
\text { Perigi Baru }\end{array}$ & Pondok Aren \\
\hline 2 & Bapak Sarmilih & Harapan Mulia & Pondok Aren \\
\hline 3 & Bapak Atim & Kelompok Tani Padi & Buaran \\
\hline 4 & Ibu Wiwin & KWTAz-zahra & Buaran \\
\hline
\end{tabular}

Interview dilakukan 17 Juni 2019 pada pukul 11:23:37. Pak Zakaria merupakan warga Kota Tangerang Selatan berusia 60 tahun dahulu beliau menanam padi namun sekarang tidak lagi karena adanya perubahan lahan menjadi jalan tol. Sekarang juga beliau menanam bukan di tanah pribadi tetapi di tanah pengembang. Bantuan pemerintah diberikan beberapa tahun lalu yang diberikan oleh BATAN. Selama ini beliau menggunakan keuangan pribadi. Pak $\mathrm{Za}-$ karia adalah ketua kelompok Harapan Baru. Kelompoknya hanya sebanyak 25 orang dan semuanya sudah berusia kepala lima. Kendala lain adalah pengairan, kalau hujan kelebihan tetapi kalau panas kekurangan, lokasi tanah dekat sungai Angke. Alat tani yang digunakan kelompok tani Harapan Baru adalah alat tradisional. Menurut Pak Zakaria kelembagaan kelompok berbadan hukum untuk mendapatkan bantuan. Untuk regulasi, Pak Zakaria tidak mengetahui tentang 
PP No. 8 tahun 2007 dan UU no. 19 tahun 2013. Pak Zakaria belum pernah mengurus badan hukum. Kemudian, Pak Zakaria membeli bibit di sekitar tapi untuk padi sudah susah. Untuk modal juga selalu kurang selalu kurang. Kemudian, untuk pelatihan, sudah lama tidak ada pelatihan melalui SL (Sekolah Lapang) Padi Sawah, cara tanam padi yang baik atau disebut Laboratorium Lapangan. Untuk Laboratorium Lapangan juga dulu ada sekarang tiada. Menurut Pak Zakaria, kelembagaan adalah hal terpenting untuk ditingkatkan.

Interview dilakukan 17 Juni 2019 pada pukul 12:13:13. Bapak Sarmilih berusia 60 tahun merupakan anggota kelompok tani Harapan Mulia. Pak Sarmilih ini merupakan petani kangkung dan bayam. Beliau tidak mengetahui apakah penting sebuah kelompok tani berbadan hukum dan tidak tahu administrasinya. Bapak Sarmilih membeli bibit di toko bibit-bibitan. Beliau kesulitan membeli bibit murah. Kenaikan harga bibit dan kenaikan harga jual tidak sebanding menurutnya. Biji kangkung perkg dulu Rp15.000 dan sekarang Rp35.000 Pak Sarmilih merupakan petani yang tidak memiliki lahan dan memakai lahan Bintaro. Bapak Sarmilih tidak memiliki HP sehingga teknologi terbaru sulit dia ketahui. Kendala pasar yang beliau hadapi bahwa harga pasar tidak bisa mahal. Pak Sarmilih memilih kangkung dan bayam karena waktu panen hanya 20 hari. Irigasi yang digunakan adalah dari Setu namun karena banyak bangunan jadi susah sehingga yang digunakan adalah empang terdekat dan hujan. Pak Sarmilih menginginkan bibit dan pupuk murah. Peraturan dan kelembagaan tidak dipahami dan tidak dimengerti oleh beliau.

Interview dilakukan pada tanggal 17 Juni 2019 pada pukul 12:32:40. Bapak Atim adalah ketua kelompok tani padi Buaran berusia 65 tahun. Pak Atim bukan asli Tangerang Selatan, baru 27 tahun di Tangerang Selatan. Pak Atim asli Indramayu dulu tinggal di panorama sekarang lahan berubah menjadi perumahan. Pak Atim terkadang kesulitan modal. Beliau membeli bibit di Parung sangat jauh dari Buaran. Bibit yang dibutuhkan rata-rata $25 \mathrm{~kg}$. Satu kilogram padi bibit seharga Rp65.000, Hambatan dalam pekerja adalah tenaga orang kurang dan mahal. Buruh tani harus dibayar 80 ribu lain makan lain rokok,dan paling mahal Rp150.000. Saat ditanya untuk kritik awalnya tidak ada masukan namun setelah dipaksa baru diberikan yaitu pupuk dan alat pertanian untuk memberantas hama. Untuk Buler, beliau belum memilikinya jadi dipinjamkan oleh dinas. Jika tidak kebagian buler maka biaya lebih mahal karena orang yang mengerjakan. Untuk hasil panen beliau menjualnya ke kampung atau ada orang datang membeli. Untuk rata-rata petani di setu atau perbatasan Parung Bogor melakukan untuk bertani. Pertemuan yang dilakukan oleh dinas tidak pasti, bisa dihitung $2 \mathrm{x}$ setahun, Pertemuan yang lain seperti pertemuan kelompok, dan anjangsono (penyuluh datang ke petani secara tidak terjadwal untuk berkomunikasi masalah tani). Kendala lain yaitu untuk pupuk, di Tangsel tidak ada distributor pupuk karena pemakaian pupuk belum 1 ton, sedangkan batas minimal pengiriman satu ton. Kalau dinas memakai uang sendiri untuk membeli satu ton itu tidak diperbolehkan. Hal ini membuat petani membeli pupuk dari luar atau dari kampungnya dengan cara sewa bus.

Interview dilakukan pada tanggal 17 Juni 2019 pada pukul 15:41:17. Ibu wiwin adalah ketua kelompok tani Az-Zahra. Dia menggarap tanah perumahan yang terbengkalai. Dia izin ke pak RW untuk mengelola tanah. Permasalahan tanah dihadapi adalah tentang hak milik tanah karena bu Wiwin bertani di atas lahan developer, jika ada perubahan kepentingan terhadap tanah maka akan diberitahu tidak mendadak. Ibu wiwin merupakan anak petani namun tanah keluarganya sudah dijual sehingga beliau tidak memiliki lahan kosong untuk menanam selain milik developer. Kegiatan pertemuan kelompok wanita ini dilakukan tiap hari. Asal muasal kelompok tani ini adalah berasal dari grup qasidahan. Awalnya kelompok wanita ini menggunakan kas masjid mengelola tanah, pertama kali, mereka bertani dengan menanam jagung. Alasan awal dari inisiatif ini adalah ibu ibu sekitar bosan sehingga membuat kegiatan. Awalnya ibu wiwin melakukannya untuk kepentingan sendiri, ternyata ada dampak lain yaitu kunjungan PAUD dan mengikuti per- 
lombaaan mewakili Tangerang Selatan sehingga membuat semangat para anggota. Bagi Kelompok Wanita Tani Lahan sangat cukup dan modal juga dari sendiri. Bagi Ibu Wiwin, mereka tidak mengharapkan bantuan. Beberapa hasil panen KWT disalurkan ke tukang sayur dan untuk pen jual kembang. Untuk Bihong dipanenkan untuk buat tabur kuburan. Untuk memotivasi, Ibu Wiwin tidak ingin menyuruh atau mengajak, Ibu Wiwin hanya mencontohkan. Dahulunya, Ibu Wiwin merupakan petani Anggrek. Tanam Anggrek sangat mahal perawatannya sehingga Ibu Wiwin tidak ingin memperkenalkan dulu tani Anggrek kepada anggotanya. Beberapa program yang dilakukan KWT Az-Zahra untuk menambah modal dan meningkatkan kegiatan di masa depan adalah misalnya dapat 100.000 maka disisihkan 50.000, juga kelebihannya KWT AzZahra sudah memiliki bank sampah. Harapan ibu Wiwin adalah lahan sendiri, bibit murah, pupuk terjangkau dan sarana produksi, dan mudahnya akses air. Kemudahan akses air ini menjadi prioritas utama karena sangat sulit mengairi tanaman setiap hari.

\section{Pembahasan}

Dari hasil di atas dapat dibahas bahwa permasalahan utama di Kota Tangerang Selatan adalah pertama, lahan yang tidak dimiliki oleh petani. Petani hanya bertani di atas lahan perumahan misalnya Bintaro Jaya dan lahan digunakan untuk jalan tol. Pengkonversian tanah dilakukan karena beberapa variabel. Menurut penelitian di Kabupaten Banyuwangi (Widya \& Pamungkas, 2013) bahwa variabel yang mempengaruhi secara langsung mengkonversian tanah dari tani dan non-tani adalah produksi, harga jual komoditas, biaya irigasi, biaya input, pendapatan di sektor non-pertanian,dan perbedaan harga sewa lahan pertanian dan pendapatan pertanian. Variabel yang tidak mempengaruhi adalah anggota keluarga berusia produktif, tingkat pendidikan petani, biaya transportasi, dan biaya informasi. Pada penelitian tersebut juga dibagi antara petani yang memiliki opportunity cost tinggi (penghasilan non-tani lebih tinggi penghasilan tani) dan opportunity cost rendah ( penghasilan tani lebih tinggi dari penghasilan non-tani). Opportunity cost tinggi lebih cepat memutuskan untuk mengkonversi lahannya. Untuk meningkatkan ketertarikan pada sektor tani dengan cara melakukan reward supply input pertanian bagi pertanian yang memiliki produktivitas yang tinggi, keringanan pajak lahan sawah, kerjasama pemerintah dan kelompok tani dalam pengembangan pasca panen (agro industry), dan sosialisasi pentingnya lahan pertanian dan terkait peraturan konversi. Sedangkan untuk menekan pertumbuhan harga lahan adalah pertama, dengan zoning regulation yang terdiri dari 3 kawasan yaitu status irigasi, indeks pertanaman, dan produktivitas lahan. Lahan yang memiliki irigasi teknis, Indeks Penanaman (IP) $>$ dua kali tanam dalam setahun dan produktivitas tinggi menjadi lahan sawah abadi. Jika lahan dapat dikonversi namun pengkonversiannya terbatas. Kedua, Memperketat Perizinan Lahan seperti Izin Lokasi Kegiatan,Izin Penggunanan Pemanfaatan Tanah, Izin Perubahan Penggunaan Tanah, dan Izin Mendirikan Bangunan. Ketiga, Memberikan pajak progresif bagi yang mengkonversi lahan ke non-pertanian untuk insentif petani sekitar. Keempat, sanksi diberikan bagi pelanggar baik administrasi dan pidana (Widya \& Pamungkas, 2013). Konversi lahan sawah juga bisa merugikan masyarakat luas tetapi tidak merugikan penjual lahan (Irawan, 2005).

Permasalahan kedua adalah pengairan, waduk dan sistem irigasi di Kota Tangerang Selatan sangat tidak terintegrasi. Seharusnya lahan tanam dekat waduk atau sungai namun yang terjadi lahan tanam jauh dari sumber air. Menurut Pasandaran (2007) Perlu adanya pembangunan sistem irigasi yang terpadu yang menopang tiga hal yaitu, fungsi produksi pertanian yang mencakup pangan, peternakan, perkebunan dan perikanan dan holtikultura, fungsi konservasi dan fungsi pewarisan sosial budaya. Untuk mencapai sistem irigasi yang baik harus dilakukan dengan integrasi penerapan prinsip-prinsip masyarakat lokal, perkembangan teknologi dan pendekatan keterpaduan. Dalam membangun sistem irigasi yang paling murah adalah sistem rawa pasang surut dan yang paling 
mahal pertama adalah pembangunan baru irigasi, kedua adalah rehabilitasi irigasi dan ketiga adalah sistem pengendalian Banjir (Pasandaran, 2007). Irigasi melalui pipa juga meningkatkan tingkat produktivitas lahan sebesar 22\% (Purwanto, Erizal, \& Anika, 2019). Irigasi yang murah untuk perkotaan yang memiliki kepadatan penduduk tinggi dan krisis air adalah penggunaan air limbah domestik yang dapat menggantikan pupuk.

Permasalahan ketiga adalah banyak petanipetani yang sudah masuk usia non-produktif atau sudah di atas 50 tahun bagi pria dan bagi wanita rata-rata ibu ibu rumah tangga yang mengisi kekosongan. Ini adalah sinyal menurunnya generasi muda tertarik dalam kelompok tani. Menurut Sutriati dan Ginting (2012) Partisipasi anggota kelompok tani dalam penguatan Lembaga Distribusi Pangan Masyarakat (LDPM) dipengaruhi oleh usia, faktor motivasi, pendapatan, dan intensitas menerima sosialisasi. Semakin muda usia anggota kelompok tani maka partisipasi naik; semakin kuat motivasi, pendapatan dan intensitas menerima sosialisasi maka semakin tinggi partisipasi. Pemilihan pengurus kelompok dirasa harus sesuai dengan ketrampilan sosial dan usaha tani (Nuryanti \& Swastika, 2011).

Pengertian kelompok tani adalah kelompok merupakan gabungan beberapa orang yang memiliki tujuan sama. Menurut Sutriati dan Ginting (2012) Keberadaan kelompok ini memiliki potensi untuk memberikan kesempatan teman teman kita untuk belajar dalam penerapan teknologi yang berdampak pada meningkatnya hasil panen. Permasalahan lahan juga dapat diatasi dengan menggabungkan tanah yang digarab menjadi satu kesatuan daripada digarab masing-masing. Potensi-potensi untuk mempercepat adopsi teknologi adalah besarnya jumlah anggota, luasnya hamparan lahan, kepatuhan petani dalam kesepakatan kelompok, pemahaman individu atas tujuan bersama, persamaan perepsi dan munculnya lembaga pembiayaan. Kendala kelompok tani saat ini adalah kelompok tani dibuat oleh pemerintah untuk melancarkan program pemerintah untuk menyalurkan bantuan seperti pupuk bersubsidi, penyuluhan teknologi pertanian, kredit usaha tani bersubsidi dan pro- gram lain bukan atas inisiatif sendiri. Konflik yang terjadi adalah kemajemukan budaya dalam menyerap teknologi baru, etos kerja dan profesionalisme sangat rendah, kesadaran anggota yang rendah untuk menjaga keutuhan dan konflik kepentingan. Untuk meningkatkan potensi maka harus dilakukan pelatihan sekolah lapang (SL) atau pelatihan kelembagaan petani untuk meningkatkan kapasitas petani bekerjasama dalam kelompok (Sutriati \& Ginting, 2012), dan menumbuhkembangkan persepsi yang sama tentang pentingnya kerjasama antar kelompok.

Kelompok tani dibentuk dari beberapa hal, yaitu, masalah distribusi pupuk, masalah bantuan sarana produksi ataupun tunai, dan pengajian (Pratama \& Samudro, 2018). Jika para petani Tangerang Selatan sulit mendapatkan bibit seperti padi dan harus jauh-jauh ke Parung Bogor untuk membelinya. Seharusnya kelompok tani dapat memberikan solusi untuk itu.

Untuk meningkatkan eksistensi sebuah kelompok tani maka ketua kelompok tersebut harus melakukan beberapa pendekatan seperti menyampaikan informasi pada saat pertemuan rutin kelompok tani dan mendatangi rumah masing-masing jika dalam pertemuan kelompok rutin tidak cukup. Hambatannya adalah anggota tidak memperhatikan dan bicara sendiri, terdapat perbedaan pendapat, dan keterbatasan waktu (Prasetyo, Safitri, \& Hidayat, 2019).

Permasalahan keempat adalah pupuk yang tidak bisa dibeli pada distributor terdekat karena ada kuota dari pembelian pupuk minimal satu ton. Permasalahan dalam pupuk bersubsidi adalah pertama, Sistem Penetapan Alokasi Pupuk dan Akurasi Data Petani, Peraturan sistem distribusi pupuk Permendag No. 21/M-DAG/PER/6/2008 mengatur proses perencanaan alokasi kebutuhan pupuk yang didasarkan oleh Rencana Definitif Kebutuhan Kelompok (RDKK) tetapi, peraturan tersebut tidak mencantumkan Kebutuhan Pupuk berdasarkan RDKK. Selain itu juga Pemda belum mempunyai data yang akurat untuk data petani terutama luas lahan sehingga fungsi pengawasan dan pengendalian kurang efektif. Kedua, implementasi tidak sesuai dengan ketentuan (moral hazard), produsen seharusnya bertanggung jawab 
sampai Lini IV (pengecer resmi) dengan HET yang berlaku. Pada prakteknya produsen pupuk tidak peduli distribusi pupuk Lini III ke Lini IV dan pemilihan distributor dilakukan acak. Ketiga, Penggunaan pupuk tidak sesuai dengan dosis anjuran, penggunaan pupuk 200-300 kg/ha. Sedangkan petani biasanya menggunakan 300$500 \mathrm{~kg} / \mathrm{ha}$ atau juga lahan yang tidak dihitung pemerintah menjadi lahan tani dialihfungsikan menjadi lahan pertanian sehingga tidak tercatat. Penggunaan pupuk yang tidak terkontrol membuat kenaikan permintaan pupuk pada awal musim tanam sehingga menjadi langka. Keempat, Harga Eceran Tertinggi (HET) kurang realistik sehingga penjual masih menaikkan lagi marjinnya. Kelima, keterbatasan anggaran belanja pemerintah yang akan mengakibatkan dua kondisi yaitu : pemberian subsidi pupuk diprioritaskan pada petani pangan skala kecil atau total volume pupuk bersubsidi hanya dihitung dari luas tanam yang belum akurat dikali dengan jumlah dosis pupuk yang direkomendasikan. Keenam, sistem distribusi tertutup yang belum optimal seperti belum tersimpulnya peraturan Permendag No.21/M-DAG/PER/6/2008 yang mengatur Lini I sampai IV dengan Permentan No. 42/Permentan/OT.140/09/2008 yang mengatur Lini IV ke petani, dan terakhir adalah masih lemahnya pengawasan di lapangan (Rachman, 2009). Kurangnya pengawasan dari departemen pertanian membuat harga pupuk di atas HET, pola pikir petani yang menggunakan pupuk melebihi dosis, pejabat yang mengambil pungli terhadap kios resmi, dan birokrasi yang terlalu panjang terhadap pendistribusian pupuk (Vidyanita, Wijaya, \& Rochmah, 2016). Berbagai kebijakan telah diterapkan oleh pemerintah dari pemberian subsidi kemudian dicabut, monopoli distribusi kemudian dicabut, tetap saja kelangkaan masih terjadi. Fakta ini membuat distribusi tidak menjadi satu satunya kendala penyebaran pupuk di Indonesia yaitu ekspor pupuk bersubsidi dan petani tidak merespon secara langsung kebijakan pupuk. Bagi petani penyuluh adalah faktor yang berperan dalam keputusan pembelian mereka dan harga jual gabah. Jadi, petani tidak menghitung keefektivan penggunaan pupuk (Darwis
\& Nurmanaf, 2004). Agar pemanfaatan subsidi pupuk efisien maka disarankan empat hal: pertama, harga gas bumi sebagai bahan pupuk urea diatur pemerintah dan ditransaksikan dalam rupiah; kedua, HET ditingkatkan secara gradual dengan proporsi yang signifikan; ketiga, dokumen RDKK pupuk bersubsidi ditingkatkan dengan cara pendampingan penyusunan RDKK dan kesesuaian angka kebutuhan pupuk (Suryana, Agustian, \& Yofa, 2016) .

Permasalahan kelima kurangnya pertemuan dari pemerintah kepada kelompok tani, walaupun ada hanya 2 kali pertahun. Permasalahan ini sesuai dengan Sandyatma (2012) bahwa peranan penyuluh tidak dapat meningkatkan partisipasi kelompok tani karena sedikitnya pertemuan.

Permasalahan keenam adalah kelompok tidak tahu regulasi yang mendukung ketahanan pangan pertanian, dan perikanan serta belum sadarnya kelompok tani menyiapkan administrasi untuk menjadi berbadan hukum sehingga berdampak kepada bantuan pemerintah yang sedikit. Kendala Ketujuh adalah belum terintegrasinya pemasaran hasil panen di Kota Tangerang Selatan karena sistem promosi yang belum mutakhir.

\section{SIMPULAN}

Peranan Dinas Ketahanan Pangan Kota Tangerang Selatan adalah merencanakan, melaksanakan, mengarahkan, mengawasi dan mengendalikan kegiatan di bidang pertanian, peternakan, dan perikanan dan ketahanan pangan sesuai kebijakan Pemerintah Daerah. Program yang dilaksanakan untuk ketahahanan pangan adalah kegiatan pengembangan kawasan mandiri pangan, pengembangan pangan, sosialisasi pertanian perkotaan, pemanfaatan pekarangan untuk kegiatan gebyar pertanian perkotaan, pengembangan pertanian lahan sempit, penguatan cadangan pangan, ketersediaan informasi pasokan, harga dan akses pangan, manajemen logistik, keamanan pangan, peningkatan mutu pangan, peningkatan keamanan pangan. Untuk program pengembangan peternakan adalah pembangunan puskewan dan unit desa mandiri benih, pelatihan pengembangan peternakan, pengadaan fasilitasi 
kegiatan hewan dan ternak, kegiatan fasilitasi kesehatan hewan, pengemdalian dan pencegahan penyakit hewan qurban, fasilitasi kesehatan masyarkat veterine. Program pengembangan perikanan adalah kegiatan pembinaan dan pengembangan perikanan, pengembangan sistem ikan dan lingkungan pembudidayaan ikan, pengembangan sarana dan prasarana kesehatan ikan dan lingkungan pembudidaya ikan, pembangunan balai benih ikan lokal Kota Tangerang Selatan tahap I, pembibitan dan perawatan ternak, pendistribusian bibit ternak kepada masyarakat, pengembangan produksi peternakan, pembangunan demplot pertanian, magang budidaya perikanan, kegiatan pengembangan penanganan pasca panen bidang peternakan, sosialisasi hasil produksi dan teknologi peternakan, temu usaha perikanan, pengembangan bibit ikan unggul. Kendala dari pertanian Kota Tangerang Selatan adalah lahan pertanian sementara, tidak ada irigasi yang memadai, menurunnya generasi muda dalam berpartisipasi dalam kelompok tani, jauhnya membeli pupuk dan bibit, kurangnya pertemuan antara kelompok tani dan pemerintah, regulasi yang tidak dipahami oleh ketua kelompok tani, permodalan yang dilakukan secara pribadi disebabkan kelompok tani yang belum berbadan hukum, dan belum terintegrasinya pemasaran hasil panen ke petani melalui tekonologi terbaru karena sistem pembeliannya masih datang ke tempat panen dan memborong.

\section{DAFTAR PUSTAKA}

Adiman. (2019, Juni 12). Kendala dan Nonkendala Pangan. (I. Lubis, Interviewer)

Atim. (2019, Juni 17). Kendala dan Nonkendala Proses Pertanian. (I. Lubis, Interviewer)

Bungin, B. (2007). PENELITIAN KUALITATIF Komunikasi, Ekonomi, Kebijakan Publik, dan Ilmu Sosial Lainnya Edisi Kedua. Jakarta: Kencana.

Darwis, V., \& Nurmanaf, A. R. (2004). Kebijakan Distribusi, Tingkat Harga, dan Penggunaan Pupuk di Tingkat Petani. Forum Penelitian Agro Ekonomi, 63-73.
Dinas Ketahanan Pangan, Pertanian dan Perikanan Kota Tangerang Selatan. (2018). Profil Dinas Ketahanan Pangan, Pertanian dan Perikanan Kota Tangerang Selatan Tahun 2017. Tangerang Selatan: Dinas Ketahanan Pangan, Pertanian dan Perikanan.

Ida. (2019, Juni 12). Kendala dan Nonkendala. (I. Lubis, Interviewer)

Irawan, B. (2005). KONVERSI LAHAN SAWAH: Potensi Dampak, Pola Pemanfaatannya, dan Faktor determinan. Forum Penelitian Agro Ekonomi, 1-18.

Irwan. (2019, Juni 12). Kendala dan Nonkendala. (I. Lubis, Interviewer)

Karini, D. M. (2013). Dampak Alih Fungsi Lahan Persawahan Terhadap Produksi Beras Dalam Rangka Ketahanan Pangan (Studi Kasus di Kabupaten Tangerang). Jurnal Ketahanan Nasional, 19, 1.

Maharisi, S., Machfud, \& Maulana, A. (2014). Manajemen Strategi Pengembangan Pertanian Kota (Urban Agriculture) di Kota Tangerang Selatan. Jurnal Aplikasi Manajemen, 351361.

Nuryanti, S., \& Swastika, D. K. (2011). Peranan Kelompok Tani dalam Penerapan Teknologi. Forum Penelitian Agro Ekonomi, 115-128.

Pasandaran, E. (2007). Pengelolaan Infrastruktur Irigasi Dalam Kerangka Ketahanan Pangan Nasional. Analisis Kebijakan Pertanian, 126149.

Prasetyo, A. S., Safitri, R., \& Hidayat, K. (2019). Strategi Komunikasi Ketua dalam Meningkatkan Eksistensi Kelompok (Kasus di Kelompok Tani Sidodadi di desa Junrejo, Kecamatan Junrejo Kota Batu Jawa TImur). Habitat, 26-34.

Pratama, Y. P., \& Samudro, B. R. (2018). Pola Pembentukan Kelompok Tani. Jurnal eBA, 21-31.

Purwanto, Y., Erizal, \& Anika, N. (2019). Peningkatan Efisiensi dan Produksi Pangan dengan Pembangunan Sistem Irigasi Pipa di TIngkat Tersier. Jurnal Irigasi, 99-109.

Putra, F. (2019, Juni 12). Kendala dan Nonkendala Pangan Kota Tangerang Selatan. (I. Lubis, Interviewer) 
Rachman, B. (2009). KEBIJAKAN SUBSIDI PUPUK: Tinjauan Terhadap Aspek Teknis, Manajemen, dan Regulasi. Analisis Kebijakan Pertanian, 131-146.

Sandyatma, Y. H. (2012). Partisipasi Anggota Kelompok Tani dalam Menunjang Efektivitas Gapoktan pada Kegiatan Penguatan Lembaga Distribusi Pangan Masyarakat di Kabupaten Bogor. Kawistara, 225-328.

Sarmilih. (2019, Juni 17). Kendala dan Non Kendala proses pertanian. (I. Lubis, Interviewer)

Suryana, A., Agustian, A., \& Yofa, R. D. (2016). Alternatif Kebijakan Subsidi Pupuk Bagi Petani Pangan. Analisiis Kebijakan Pertanian, 35-54.

Sutriati, A., \& Ginting, N. T. (2012). Potensi Air Limbah Domestik Sebagai Air Irigasi pada
Daerah Padat Penduduk dan Krisis Air. Jurnal Irigasi, 87-98.

Vidyanita, V., Wijaya, A. F., \& Rochmah, S. (2016). Kinerja Birokrasi dalam Penyaluran Pupuk Bersusidi di Kecamatan Jombang. Jurnal Ilmu Sosial dan Ilmu Politik, 74-85.

Widya, M. E., \& Pamungkas, A. (2013). Pengendalian Konversi Lahan Pertanian Pangan Menjadi Non Pertanian Berdasarkan Preferensi Petani di Kecamatan Wongsorejo, Kabupaten Banyuwangi. Jurnal Teknik Pomits, 2337-3539.

Wiwin. (2019, Juni 17). Kendala dan Nonkendala Pangan. (I. Lubis, Interviewer)

Zakaria. (2019, Juni 17). Kendala dan Nonkendala Pangan. (I. Lubis, Interviewer) 